\title{
ANALISIS PENGARUH CAR DAN FDR TERHADAP EQUIVALENT RATE DEPOSITO SERTA DAMPAKNYA TERHADAP TOTAL ASET PADA INDUSTRI PERBANKAN SYARIAH DI INDONESIA PERIODE JANUARI 2013 - APRIL 2018 DENGAN PATH ANALYSIS
}

\author{
Argya Kirana Hasanah Raharyan \\ Departemen Ekonomi Syariah - Fakultas Ekonomi dan Bisnis - Universitas Airlangga \\ Email: argyaraharyan04@gmail.com
}

\author{
Atina Shofawati \\ Departemen Ekonomi Syariah - Fakultas Ekonomi dan Bisnis - Universitas Airlangga \\ Email: atina-o@feb.unair.ac.id
}

\begin{abstract}
:
This study aims to determine the influence of CAR and FDR on Deposit Equivalent Rate, which then re-analyzed its impact on Total Asset at Sharia Commercial Bank and Sharia Business Unit in Indonesia. This study used Path Analysis with quantitative approach. The data used in this research are secondary data obtained from the official site of the Financial Services Authority (OJK). The result of Regression Model 1 revealed that CAR and FDR simultaneously have significant influence on Deposit Equivalent Rate, evidenced by the significance value below alpha of 0,05. The other result (Regression Model 2) showed that CAR, FDR, and Deposit Equivalent Rate simultaneously have significant effect on Total Asset, which is also evidenced by the significance value below alpha of 0,05.
\end{abstract}

Keywords: CAR, FDR, Equivalent Rate, Total Asset, Sharia Banks

\section{PENDAHULUAN}

Salah satu upaya Indonesia untuk menaikkan nilai perekonomian secara bertahap adalah dengan mengembangkan sistem lembaga keuangan syariah. Lembaga keuangan syariah berpegang teguh kepada prinsipprinsip Islam, diantaranya menghilangkan bunga, menghindari ketidakjelasan dan menghapus ketidakadilan. Indonesia memiliki jumlah bank sebanyak 120 menurut Badan Pusat Statistik pada tahun 2013. Namun, pada awal tahun 2017 menurut data Otoritas Jasa Keuangan (OJK) jumlah bank di Indonesia sudah mengalami pengurangan yaitu menjadi 116 bank. Hal ini menunjukkan melambatnya pertumbuhan ekonomi Indonesia.
Melambatnya pertumbuhan ekonomi Indonesia sudah dimulai dari

tahun 2014, ekonomi Indonesia tumbuh sebesar 5,02\% lebih rendah dari tahun sebelumnya yaitu sebesar 5,58\% (OJK, 2015). Lahir dan berkembangnya perbankan syariah di Indonesia merupakan salah satu langkah untuk menghapus sistem riba yang secara perlahan merugikan masyarakat. Bank syariah menawarkan beragam produk kepada nasabah. Produk pada perbankan syariah pada dasarnya dibagi menjadi tiga bagian besar yaitu produk penyaluran dana (financing), produk penghimpunan dana (funding) dan produk jasa (service) (Karim, 2014:97). Perbankan Syariah menggunakan perhitungan Equivalent Rate untuk

1) Jurnal ini merupakan bagian dari skripsi Argya Kirana Hasanah Raharyan, NIM: 041411433013, yang diuji pada tanggal 20 Juli 2018. 
Raharyan, et al/Jurnal Ekonomi Syariah Teori dan Terapan Vol. 6 No. 2 Februari 2019: 243-253; ANALISIS PENGARUH CAR DAN FDR TERHADAP EQUIVALENT RATE DEPOSITO SERTA DAMPAKNYA TERHADAP TOTAL ASET PADA INDUSTRI PERBANKAN SYARIAH DI INDONESIA PERIODE JANUARI 2013 - APRIL 2018 DENGAN PATH ANALYSIS

menggantikan sistem perhitungan bunga dalam setiap jenis pola sistem bagi hasil yang ada. Perhitungan dengan metode Equivalent Rate juga menjadi salah satu indikator nasabah untuk beralih dari bank konvensional. Equivalent Rate Deposito sendiri merupakan hasil konversi ke persentase dari nisbah bagi hasil simpanan mudharabah yang bersifat nominal (Setyarini \& Hernama, 2005). Penelitian yang dilakukan oleh Susanti (2015) tentang Pengaruh Equivalent Rate dan Tingkat Keuntungan Terhadap Dana Pihak Ketiga (DPK) Perbankan Syariah di Indonesia menggunakan teknik regresi linear berganda. Hasil pengujian menunjukkan bahwa Equivalent Rate berpengaruh positif dan signifikan terhadap Dana Pihak Ketiga perbakan syariah di Indonesia, artinya apabila Equivalent Rate naik maka jumlah DPK juga akan ikut naik. Selanjutnya, tingkat keuntungan juga berpengaruh positif dan signifikan terhadap DPK perbankan syariah. Secara simultan Equivalent Rate dan tingkat keuntungan berpengaruh signifikan terhadap Dana Pihak Ketiga perbankan syariah di Indonesia.

Penelitian selanjutnya dilakukan oleh Masruroh dan Effendi (2016) tentang Analysis The Profit Distribuiton Management (PDM) Sharia Bank in Indonesia Period 2010-2014. Hasil penelitian tersebut menunjukkan secara simultan variabel independen berpengaruh signifikan terhadap variabeldependen yang dibuktikan dengan nilai signifikansi lebih kecil dari alpha 0,05 .

Penelitian yang dilakukan oleh Djuwita dan Mohammad (2015) juga menjadi acuan dalam penelitian ini yaitu tentang Pengaruh Total DPK, FDR, NPF dan ROA terhadap Total Asset Bank Syariah di Indonesia. Hasil dari penelitian ini menunjukkan bahwa a secara bersamasama variabel DPK, FDR, ROA, dan NPF berpengaruh signifikan terhadap total asset bank syariah. Secara parsial, hanya DPK, FDR, dan NPF yang berpengaruh signifikan, sedangkan ROA tidak berpengaruh.

Penelitian ini berfokus pada faktor yang berpengaruh terhadap Equivalent Rate Deposito yaitu faktor pertama CAR dan kedua FDR yang kemudian akan diujikan kembali pengaruhnya terhadap total aset. Menurut Kasmir (2014:46) CAR merupakan perbandingan rasio tersebut, antara rasio modal terhadap Aktiva Tertimbang Menurut Risiko dan sesuai dengan ketentuan pemerintah. FDR diartikan sebagai rasio yang digunakan untuk mengukur likuiditas suatu bank dalam membayar kembali penarikan dana yang dilakukan deposan dengan mengandalkan pembiayaan yang diberikan sebagai sumber likuiditasnya (Wahyu, 2016).

Penelitian ini menggunakan Teknik sampling yang digunakan dalam penelitian ini adalah teknik Sampling Jenuh. Teknik Sampling Jenuh adalah teknik penentuan sampel bila semua anggota populasi digunakan menjadi 
Raharyan, et al/Jurnal Ekonomi Syariah Teori dan Terapan Vol. 6 No. 2 Februari 2019: 243-253; ANALISIS PENGARUH CAR DAN FDR TERHADAP EQUIVALENT RATE DEPOSITO SERTA DAMPAKNYA TERHADAP TOTAL ASET PADA INDUSTRI PERBANKAN SYARIAH DI INDONESIA PERIODE JANUARI 2013 - APRIL 2018 DENGAN PATH ANALYSIS

sampel atau untuk penelitian yang inginmembuat generalisasi dengan tingkat kesalahan yang kecil atau sedikit (Sugiyono, 2011:68). Sampel yang digunakan dalam penelitian ini adalah industri perbankan syariah Indonesia yaitu seluruh BUS dan UUS yang tercatat pada Otoritas Jasa Keuangan periode Januari 2013 hingga April 2018. Data yang tercatat oleh Otoritas Jasa Keuangan pada Desember 2017, jumlah Bank Umum Syariah (BUS) di Indonesia sebesar 13 bank. Sedangkan Unit Usaha Syariah (UUS) yang tercatat oleh Otoritas jasa Kevangan hingga Desember 2017 menunjukkan angka sebesar 34 bank. Teknik analisis yang digunakan dalam penelitian ini adalah dengan teknik analisis jalur (Path Analysis) dengan dua model regresi. Berdasarkan uraian yang telah dijelaskan, maka rumusan masalah dalam penelitian ini adalah: (1) Apakah CAR dan FDR berpengaruh terhadap Equivalent Rate Deposito? (2) Apakah CAR, FDR, dan Equivalent Rate Deposito berpengaruh terhadap Total Aset pada Industri Perbankan Syariah di Indonesia Periode Januari 2013-April 2018?

\section{LANDASAN TEORI}

\section{Bank Syariah}

Bank syariah adalah lembaga keuangan yang usaha pokoknya memberikan pembiayaan dan jasa-jasa lainnya, dalam lalu lintas pembayaran serta peredaran uang yang pengoperasiannya di sesuaikan dengan prinsip Islam (Muhammad, 2014:13). Tarsidin (2003:55) mengatakan bahwa menurut definisi, bank Islam merupakan bank yang tunduk pada hukum Islam (syariat). Bank Islam memiliki beberapa elemen yang harus terlibat didalamnya yaitu : (1) Riba dilarang dalam semua transaksi; (2) Bisnis dan investasi dijalankan berdasarkan aktivitas-aktivitas yang halal; (3) Transaksi harus bebas dari unsur gharar (spekulasi atau ketidakpastian yang tidak masuk akal); (4) Zakat harus dibayar oleh bank untuk dimanfaatkan masyarakat; (5) Semua aktivitas harus sejalan dengan prinsip-prinsip Islam, dengan dewan syariah khusus bertindak sebagai penyelia dan memberikan nasihat kepada bank mengenai kepatutan suatu transaksi.

\section{Sistem Bagi Hasil}

Sistem bagi hasil merupakan salah satu alternatif untuk menghindari perhitungan bunga yang digunakan oleh perbankan syariah. Menurut Karim (2014:203) sesungguhnya bagi hasil itu hanya merupakan bagian saja dari sistem operasi bank syariah. Karim (2014:203) juga menjelaskan bahwa bagi hasil adalah bentuk return dari kontrak investasi, yakni yang termasuk ke dalam natural uncertainty contracts (kontrak/akad dalam bisnis yang tidak memberikan kepastian pendapatan, baik dari segi jumlah maupun waktunya).

\section{Tingkat Imbal Bagi Hasil (Ekuivalen)}

Equivalent Rate bagi hasil merupakan hasil konversi dari nisbah bagi hasil simpanan mudharabah yang bersifat nominal (Setyarini, 2005). Menurut Antonio (2001:160) Equivalent Rate Bagi Hasiltabungan adalah jumlah bagi hasil 
Raharyan, et al/Jurnal Ekonomi Syariah Teori dan Terapan Vol. 6 No. 2 Februari 2019: 243-253; ANALISIS PENGARUH CAR DAN FDR TERHADAP EQUIVALENT RATE DEPOSITO SERTA DAMPAKNYA TERHADAP TOTAL ASET PADA INDUSTRI PERBANKAN SYARIAH DI INDONESIA PERIODE JANUARI 2013 - APRIL 2018 DENGAN PATH ANALYSIS

untuk seorang nasabah per bulan dibagi dengan saldo rata-rata tabungan nasabah tersebut yang dinyatakan dalam bentuk persentase. Peran Equivalent Rate memiliki kemiripan dengan tingkat bunga bank konvensional, namun perbedaan mendasar terletak pada waktu penetapan. Bank konvensional menjanjikan pengembalian berdasarkan tingkat bunga yang telah ditetapkan di awal kontrak, sedangkan perhitungan Equivalent Rate dihitung oleh pihak bank setiap akhir bulan setelah investasi yang dijalankan memberikan hasil.

\section{Aset Bank}

Sholihin (2010:103) mendefiniskan aset bank syariah adalah sesuatu yang menimbulkan aliran kas positif atau manfaat ekonomi lainnya, yang haknya didapat oleh bank Islam sebagai hasil dari transaksi atau peristawa pada masa lalu.Aktiva menurut Ismail (2010:16) adalah harta kekayaan tertentu yang dimiliki oleh bank pada tanggal tertentu. Pernyataan Standar Akuntansi Keuangan (PSAK) No. 16 Revisi Tahun 2011 menyebutkan bahwa aset adalah semua kekayaan yang dimiliki oleh individu ataupun kelompok yang berwujud maupun tidak berwujud, yang memiliki nilai akan memiliki manfaat bagi tiap orang atau perusahaan tersebut.

\section{Tingkat Kecukupan Modal}

Pasal 29 UU RI No 10 Tahun 1998 menyebutkan bahwa bank wajib memelihara tingkat kesehatan bank sesuai dengan ketentuan kecukupan modal, kualitas aset, kualitas manajemen, likuiditas, rentabilitas, solvabilitas, dan aspek lain yang berhubungan dengan usaha bank, dan wajib melakukan kegiatan usaha sesuai dengan prinsip kehati-hatian. Laporan Implementasi Basel II yang diterbitkan oleh Bank Indonesia menyebutkan bahwa permodalan pada umumnya berfungsi sebagai penyangga terhadap kemungkinan terjadinya kerugian. Menurut Darmawi (2011:91), salah satu komponen faktor permodalan adalah kecukupan modal, rasio untuk menguji kecukupan modal bank yaitu rasio CAR (Capital Adequacy Ratio). CAR adalah adalah rasio yang memperlihatkan seberapa jauh seluruh aktiva bank yang mengandung risiko (kredit, surat berharga, dll) ikut dibiayai dari dana modal sendiri bank disamping memperoleh dana-dana dari sumbersumber di luar bank, seperti dana dari masyarakat, pinjaman, dan lain-lain (Dendawijaya, 2000:122).

\section{Tingkat Likuiditas}

Likuiditas dana merupakan salah satu aspek penting dalam perusahaan, karena likuiditas dana menentukan kemampuan sebuah perusahaan untuk membayar kewajibannya. Menurut Kasmir (2016:129) penyebab utama kejadian kekurangan dan ketidakmampuan perusahaan untuk membayar kewajiban tersebut sebenarnya adalah akibat kelalaian manajemen perusahaan dalam menjalankan usahanya. Kasmir (2016:129) menambahkan penyebab lain adalah sebelumnya pihak manajemen perusahaan tidak menghitung rasio keuangan yang diberikan, sehingga tidak 
Raharyan, et al/Jurnal Ekonomi Syariah Teori dan Terapan Vol. 6 No. 2 Februari 2019: 243-253; ANALISIS PENGARUH CAR DAN FDR TERHADAP EQUIVALENT RATE DEPOSITO SERTA DAMPAKNYA TERHADAP TOTAL ASET PADA INDUSTRI PERBANKAN SYARIAH DI INDONESIA PERIODE JANUARI 2013 - APRIL 2018 DENGAN PATH ANALYSIS

mengetahui bahwa kondisi perusahaan sudah tidak mampu.

\section{Hipotesis dan Model Analisis}

Berdasarkan

rumusan

masalah dan landasan teori, hipotesis dan model analisis dari penelitian ini adalah.

$\mathrm{Hl}$ : CAR secara parsial berpengaruh terhadap Equivalent Rate Deposito

H2 : FDR secara parsial berpengaruh terhadap Equivalent Rate Deposito

H3 : CAR dan FDR secara simultan berpengaruh terhadap Equivalent Rate Deposito

$\mathrm{H} 4$ : CAR secara parsial berpengaruh terhadap Total Aset

H5 : FDR secara parsial berpengaruh terhadap Total Aset

H6 : CAR, FDR, dan Equivalent Rate Deposito secara simultan berpengaruh terhadap Total Aset

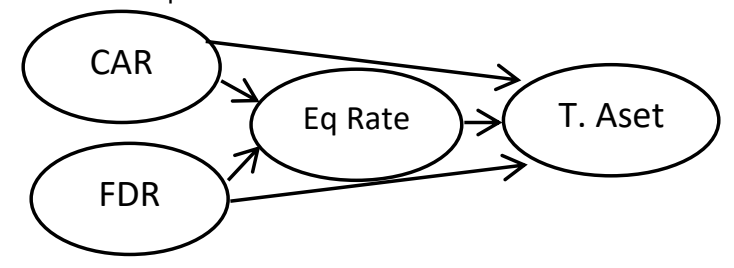

\section{Gambar 1. Model Analisis}

\section{METODE PENELITIAN}

Pendekatan dalam penelitian ini adalah pendekatan kuantitatif.Data sekunder dalam penelitian ini didapatkan dari laporan Statistik Perbankan Syariah Bank Umum Syariah (BUS) dan Unit Usaha Syariah (UUS) yang diterbitkan oleh Otoritas Jasa Keuangan.Alat uji statistic yang digunakan dalam penelitian ini adalah SPSS Versi 23.Uji yang digunakan adalah Uji Asumsi Klasik yaitu Uji Normalitas, Multikolinearitas, Autokorelasi, dan Heteroskedastisitas.Selanjutnya Uji simultan F dan Uji Parsial T.

\section{Definisi Operasional Variabel}

1. Rasio Kecukupan Modal (CAR) Dendawijaya (2000:122) adalah rasio yang memperlihatkan seberapa jauh seluruh aktiva bank yang mengandung risiko (kredit, surat berharga, dll) ikut dibiayai dari dana modal sendiri bank disamping memperoleh dana-dana dari sumbersumber di luar bank, seperti dana dari masyarakat, pinjaman, dan lain-lain.

CAR $=\frac{\text { Modal Bank }}{\text { Aktiva Tertimbang Menurut Risiko }} \times 100 \%$

2. Rasio Likuiditas Bank (FDR) Kasmir (2010:225) mendefinisikan Loan to Deposit Ratio (LDR) merupakan rasio yang digunakan untuk mengukur komposisi jumlah kredit yang diberikan dibandingkan dengan jumlah dana masyarakan dan modal sendiri yang digunakan.

$$
F D R=\frac{\text { Total Pembiayaan }}{\text { Dana yang diterima }} x 100 \%
$$

3. Equivalent Rate Equivalent Rate merupakan tambahan atau tingkat imbalan untuk nasabah penyimpan dari suatu penanaman atau investasi dana yang diberikan bank. Equivalent Rate juga diartikan sebagai tingkat pengembalian atas investasi yang telah ditanamkan (Susanti, 2015).

Eq Rate $=\frac{\text { Nominal Pendapatan DM } 1 \text { Bulan } x 12}{\text { Saldo Rata }- \text { rata DM } 1 \text { Bulan }} \times 100 \%$

4. Aset Bank Aset menurut Munawir (2002:30) adalah sarana atau sumber 
Raharyan, et al/Jurnal Ekonomi Syariah Teori dan Terapan Vol. 6 No. 2 Februari 2019: 243-253; ANALISIS PENGARUH CAR DAN FDR TERHADAP EQUIVALENT RATE DEPOSITO SERTA DAMPAKNYA TERHADAP TOTAL ASET PADA INDUSTRI PERBANKAN SYARIAH DI INDONESIA PERIODE JANUARI 2013 - APRIL 2018 DENGAN PATH ANALYSIS

daya ekonomik yang dimiliki oleh suatu kesatuan usaha atau perusahaan yang harga perolehan dan nilai wajarnya harus diukur secara objektif. searah mengikuti garis.Secara singkat, dapat disimpulkan Model Regresi 1 dan 2 berdistribusi normal.

Uji Multikolinearitas

Tabel 1.

Total Aset $=$ Aktiva Lancar + Aktiva Tetap + Aktiva Lain - lain Hasil Uji Multikolinearitas

\section{HASIL DAN PEMBAHASAN}

Uji Asumsi Klasik

Uji Normalitas

Uji normalitas adalah uji untuk mengukur apakah data yang dimiliki berdistribusi normal sehingga dapat dipakai dalam statistic parametric, jika data tidak berdistribusi normal dapat dipakai statistic non parametric (Sujarweni, 2015:120).

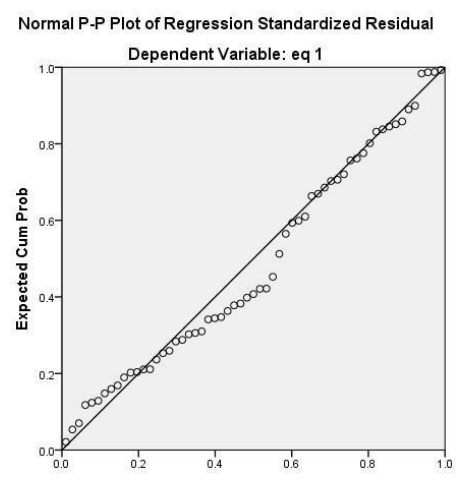

Gambar 2. Hasil Uji Normalitas Model 1

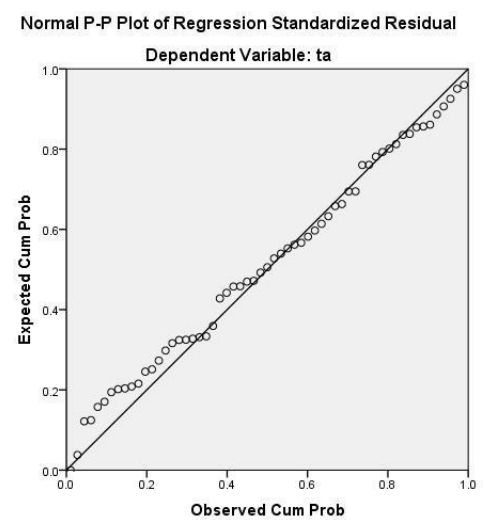

Gambar 3. Hasil Uji Normalitas Model 2

Gambar 2 dan 3menunjukkan titiktitik data menyebar di sekitar garis diagonal dan daerah penyebarannya

\begin{tabular}{|l|l|l|l|}
\hline Variabel & Tolerance & VIF & Kesimpulan \\
\hline CAR & .556 & 1.798 & Bebas Multikolinearitas \\
\hline FDR & .515 & 1.940 & Bebas Multikolinearitas \\
\hline Eq Rate & .752 & 1.329 & Bebas Multikolinearitas \\
\hline \multicolumn{2}{|c|}{ Tabel 1 diatas menunjukkan }
\end{tabular}

bahwa seluruh variabel bebas dalam penelitian ini memiliki nilai Tolerance lebih besar dari 0,01 dan nilai VIF kurang dari 10, Dengan demikian, dapat disimpulkan tidak terdapat masalah multikolinearitas pada variabel serta model regresi ini layak untuk digunakan dalam penelitian.

Uji Autokorelasi

Tabel 2.

Hasil Uji Autokorelasi

\begin{tabular}{|l|l|l|}
\hline Model & $\begin{array}{l}\text { Durbin- } \\
\text { Watson }\end{array}$ & Kesimpulan \\
\hline 1 & .372 & Bebas Autokorelasi \\
\hline 2 & 1.081 & Bebas Autokorelasi \\
\hline
\end{tabular}

menggunakan Uji Durbin Watson Test. Hasil tidak adanya masalah autokorelasi dilihat dari nilai DW Test, apabila nilai berada diantara -2 dan +2 , maka dapat disimpulkan tidak ada masalah autokorelasi. 
Raharyan, et al/Jurnal Ekonomi Syariah Teori dan Terapan Vol. 6 No. 2 Februari 2019: 243-253; ANALISIS PENGARUH CAR DAN FDR TERHADAP EQUIVALENT RATE DEPOSITO SERTA DAMPAKNYA TERHADAP TOTAL ASET PADA INDUSTRI PERBANKAN SYARIAH DI INDONESIA PERIODE JANUARI 2013 - APRIL 2018 DENGAN PATH ANALYSIS

Uji Heteroskedastisitas

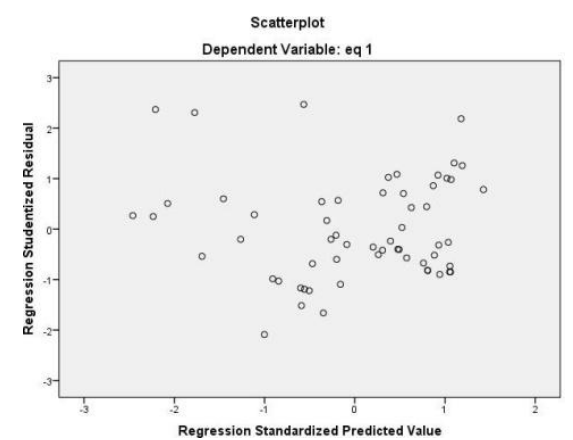

Gambar 4. Hasil Uji Heteroskedastisitas

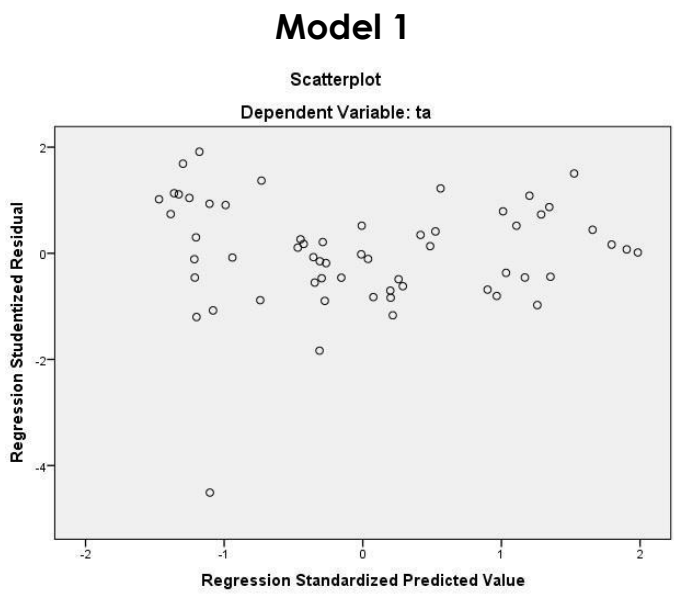

Gambar 5. Hasil Uji Heteroskedastisitas

Model 2

Uji Heteroskedastisitas untuk mengetahui ada tidaknya hubungan antar variabel pengganggu dengan variabel bebasnya. Hasil menunjukkan bahwa titik-titik data tidak mengumpul pada bagian tertentu saja dan menyebar, serta tidak berpola, sehingga Uji Heteroskedastisitas pada Model Regresi 1 dan 2 dapat disimpulkan tidak terjadi masalah Heteroskedastisitas.

\section{Pembahasan}

Pengaruh CAR Secara Parsial terhadap Equivalent Rate Deposito.

Hasil uji T diatas adalah hasil dari pengaruh CAR (XI) terhadap Equivalent Rate Deposito (Y). Nilai T Hitung sebesar 3,391 lebih besar dari nilai T Tabel dan dengan nilai signifikansi sebesar 0,001, menunjukkan bahwa variabel CAR berpengaruh negatif signifikan terhadap tingkat Equivalent Rate Deposito. Hubungan negatif antara CAR dengan Equivalent Rate Deposito, yang berarti bahwa jika terjadi peningkatan pada CAR, maka akan terjadi penurunan pada Equivalent Rate Deposito. Hal ini berkaitan dengan penelitian yang dilakukan oleh Lahrech dkk., (2014) yaitu djelaskan oleh prinsip bahwa bank perlu meningkatkan modal yang cukup di luar untuk menyerap kerugian. Hubungan negatif antara CAR dengan Equivalent Rate Deposito juga dapat disebabkan oleh besarnya minat nasabah untuk berinvestasi pada bank syariah menjadikan tingkat profit bank akan meningkat, oleh karena itu bank tetap berapa pada zona aman dalam kecukupan modal, namun tidak secara langsung memberikan dampak bahwa nilai persentase Equivalent Rate bagi hasil yang di distribusikan akan meningkat.

Pengaruh FDR Secara Parsial terhadap Equivalent Rate Deposito

Nilai T Hitung sebesar -4.101 lebih besar dari nilai T Tabel dan dengan nilai signifikansi sebesar 0,000 menunjukkan bahwa FDR berpengaruh negatif terhadap Equivalent Rate Deposito. Hubungan negatif FDR terhadap Equivalent Rate Deposito diartikan jika nilai FDR naik, maka nilai Equivalent Rate Deposito akan turun. Sejalan dengan penelitian Lahrech dkk., (2014) yang memprediksikan bahwa tingkat likuiditas yang semakin tinggi akan mendorong 
Raharyan, et al/Jurnal Ekonomi Syariah Teori dan Terapan Vol. 6 No. 2 Februari 2019: 243-253; ANALISIS PENGARUH CAR DAN FDR TERHADAP EQUIVALENT RATE DEPOSITO SERTA DAMPAKNYA TERHADAP TOTAL ASET PADA INDUSTRI PERBANKAN SYARIAH DI INDONESIA PERIODE JANUARI 2013 - APRIL 2018 DENGAN PATH ANALYSIS

bank Islam untuk mengelola semakin sedikit profitsharing ratio dan mengalokasikan lebih banyak untuk IAHs (Investment Account Holder). Lahrech dkk, (2014) menambahkan bahwa pengaruh rasio likuiditas terhadap rasio distribusi profit mempunyai hubungan yang signifikan, dibuktikan dengan hasil perhitungan statistik pada level signifikansi sebesar $10 \%$.

\section{Pengaruh CAR dan FDR Secara Simultan terhadap Equivalent Rate Deposito}

Berdasarkan Uji $F$ yang telah dilakukan, hasil pengujian menunjukkan nilai sebesar 9,211 lebih besar dari F Tabel, dengan nilai signifikansi sebesar 0,000 lebih kecil dari alpha 0,05. Hal ini menunjukkan bahwa perhitungan nilai persentase yang dilakukan oleh pihak bank merujuk pada kesehatan keuangan bank yaitu beberapa diantaranya adalah rasio kecukupan modal (CAR) dan rasio likuiditas (FDR). Kinerja keuangan yang baik akan meningkatkan kepercayaan nasabah untuk menggunakan produk yang ditawarkan. Semakin tinggi tingkat kepercayaan nasabah akan meningkatkan kualitas bank yang salah satunya dapat dilihat dari semakin membaiknya kinerja keuangan.

\section{Pengaruh CAR Secara Parsial terhadap Total Aset}

Hasil dari uji parsial CAR terhadap total aset menunjukkan bahwa CAR memiliki pengaruh signifikan dan positif. Hal ini ditunjukkan dari nilai T hitung lebih besar dari T Tabel dengan nilai signifikansi sebesar 0,002 dibawah nilai alpha sebesar
0,05 . Pengaruh signifikan dan positif ini dapat diartikan bahwa jika terjadi peningkatan pada rasio kecukupan modal (CAR) maka Total Aset yang diperoleh juga mengalami peningkatan. Sejalan dengan pernyataan Ali dalam Djuwita dan Mohammad (2016) yang menyatakan bahwa makin besar modal suatu bank, maka makin tinggi pula leverage yang dimiliki oleh bank dalam menghimpun dana pihak ketiga yang memungkinkan pula bank memperbesar earning assetnya untuk memaksimalkan keuntungan atau nilai saham pemilik bank.

\section{Pengaruh FDR Secara Parsial terhadap Total Aset}

Hasil uji parsial yang dirangkum pada Tabel diatas menunjukkan nilai $T$ Hitung sebesar -18,272 diatas nilai T Tabel sebesar 2,00404 dan nilai signifikansi sebesar 0,000 yaitu lebih kecil dari 0,005 maka dapat dikatakan bahwa FDR berpengaruh signifikan negatif secara parsial terhadap Total Aset. Hasil ini sejalan dengan penelitian yang dilakukan oleh Syafrida dan Abror (2011) yang menunjukkan hubungan negatif antara peningkatan FDR dengan pertumbuhan aset perbankan syariah di Indonesia. Syafrida dan Abror (2011) menjelaskan setiap perubahan pada FDR akan menyebabkan perubahan pula pada pertumbuhan aset perbankan syariah di Indonesia yaitu apabila terjadi peningkatan pada FDR maka likuiditas pada bank menjadi lebih sedikit, sehingga 
Raharyan, et al/Jurnal Ekonomi Syariah Teori dan Terapan Vol. 6 No. 2 Februari 2019: 243-253; ANALISIS PENGARUH CAR DAN FDR TERHADAP EQUIVALENT RATE DEPOSITO SERTA DAMPAKNYA TERHADAP TOTAL ASET PADA INDUSTRI PERBANKAN SYARIAH DI INDONESIA PERIODE JANUARI 2013 - APRIL 2018 DENGAN PATH ANALYSIS

jumlah aset lancar menjadi berkurang dan aset secara total juga akan berkurang.

Pengaruh CAR, FDR, dan Equivalent Rate Deposito Secara Simultan terhadap Total Aset

Berdasarkan uji simultan yang telah dilakukan, hasilnya menunjukkan nilai $F$ Hitung lebih besar dari $F$ Tabel dan nilai signifikansi sebesar 0,000 yaitu lebih kecil dari alpha 0,05 sehingga dapat disimpulkan bahwa CAR, FDR, dan Equivalent Rate Deposito berpengaruh signifikan terhadap Total Aset pada industri perbankan syariah di Indonesia. Hal ini dapat diartikan bahwa Total Aset yang diperoleh BUS dan UUS dapat ditentukan oleh tingkat rasio kecukupan modal (CAR), rasio likuiditas (FDR) dan nilai persentase nisbah bagi hasil. Banyak faktor yang memengaruhi total aset perbankan syariah, peningkatan total aset suatu bank ditentukan pada kemampuan bank dalam menghimpun dana baik dari permodalan ataupun dana dari pihak ketiga (Djuwita \& Muhammad, 2016).

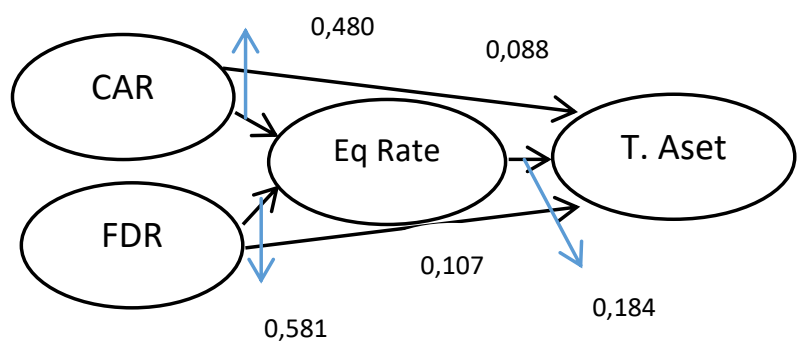

\section{Gambar 6. Model Path Analysis \\ V. SIMPULAN}

Berdasarkan analisis serta pengujian hipotesis yang telah diuraikan, maka dapat ditarik kesimpulan sebagai berikut: 1. CAR memiliki pengaruh negatif signifikan secara parsial terhadap Equivalent Rate Deposito.

2. FDR memiliki pengaruh negatif signifikan secara parsial terhadap equivalent rate deposito.

3. CAR dan FDR memiliki pengaruh positif signifikan secara simultan terhadap equivalent rate deposito

4. CAR memiliki pengaruh positif signifikan secara parsial terhadap total aset

5. FDR memiliki pengaruh negatif signifikan secara parsial terhadap total aset

6. CAR, FDR, Equivalent rate memiliki pengaruh positif signifikan secara simultan terhadap total aset

\section{DAFTAR PUSTAKA}

Algoud, Latifa M. dan Lewis, Mervyn K. 2003. Perbankan Syariah : Prinsip, Praktik, dan Prospek. Diterjemahkan Oleh : Burhan Wirasubrata. Jakarta : Serambi.

Djuwita, D., \& Muhammad, A. F. 2016. Pengaruh Total DPK, FDR, NPF dan ROA terhadap Total Asset Bank Syariah di Indonesia. Jurnal Kajian Ekonomi Dan Perbankan Syari'ah, 281-297.

Farook, S., Hassan, M. K., \& Clinch, G. 2012. Profit Distribution Management by Islamic Banks: An Empirical Investigation. Quarterly Review of Economics and Finance, 52(3), 333- 347.

Ismail. 2010. Akuntansi Bank : Teori dan Aplikasi dalam Rupiah. Jakarta : Prenada Media Group. 2011. Perbankan Syariah. Jakarta: Prenada Media Group. 
Raharyan, et al/Jurnal Ekonomi Syariah Teori dan Terapan Vol. 6 No. 2 Februari 2019: 243-253; ANALISIS PENGARUH CAR DAN FDR TERHADAP EQUIVALENT RATE DEPOSITO SERTA DAMPAKNYA TERHADAP TOTAL ASET PADA INDUSTRI PERBANKAN SYARIAH DI INDONESIA PERIODE JANUARI 2013 - APRIL 2018 DENGAN PATH ANALYSIS

Karim, Adiwarman. 2014. Bank Islam Analisis Figh dan Kevangan. Edisi Kelima. Jakarta : PT RajaGrafindo Persada.

Kasmir. 2009. Bank dan Lembaga Kevanga Lainnya. Jakarta : PT RajaGrafindo Persada.

2010. Dasar-Dasar Perbankan. Jakarta : PT RajaGrafindo Persada. 2016. Analisis Laporan Kevangan. Jakarta : PT RajaGrafindo Persada. Lahrech, N., Lahrech, A., \& Boulaksil, Y. 2014. Transparency and Performance in Islamic Banking: Implications on Profit Distribution. International Journal of Islamic and Middle Eastern Finance and Management, 7(1), 61-88.

Machmud, A., \& Rukmana. 2010. Bank Syariah: Teori, Kebijakan, dan Studi Empiris di Indonesia. Jakarta: Erlangga.

Masruroh, Fitriani dan Rohman Effendi. Analysis The Profit Distribution Management (PDM) Sharia Bank in Indonesia Period 2010-2014. 2016. Artikel Ilmiah Mahasiswa 2016.

Muhammad. 2014. Manajemen Keuangan Syariah (1st ed.). Yogyakarta: UPP STIM YKPN.

Murni, Asfia. 2009. Ekonomika Makro. Bandung : PT Refika Aditama.

Mursid, A., \& Suhartono, E. 2014. Faktor Determinan Nasabah dalam Pemilihan Bank Syariah. Jurnal Dinamika Manajemen, 5(4), 45-58.

Oktaviana, Ulfi Kartika. 2012. Financial Ratio to Distinguish Banks, Islamic
Business Units and Conventional Banks in Indonesia. Jakarta : Kementrian Agama RI Direktorat Jenderal Pendidikan Islam.

Riduwan dan Kuncoro, Engkos. 2012. Cara Menggunakan dan Memaknai Path Analysis (Analisis Jalur). Bandung : Alfabeta.

Rosyidi, Suherman. 2014. Pengantar Teori Ekonomi : Pendekatan Kepada Teori Ekonomi Mikro dan Makro. Edisi Revisi. Jakarta : PT RajaGrafindo Persada.

Suharso, Puguh. 2009. Metode Penelitian Kuantitatif untuk Bisnis : Pendekatan Filosofis dan Praktis. Jakarta : Indeks.

Sujarweni, V. Wiratna. 2015. Metodologi Penelitian Bisnis dan Ekonomi. Yogyakarta : PUSTAKABARUPRESS.

Susanti, V. 2015. Pengaruh Equivalent Rate dan Tingkat Keuntungan Terhadap Dana Pihak Ketiga (DPK) Perbankan Syariah di Indonesia. I Finance, Vol. 1. No(Juli 2015), 20.

Syafrida, I., \& Abror, A. 2011 . Faktor-Faktor Internal Dan Eksternal Yang Mempengaruhi Pertumbuhan Aset Perbankan Syariah Di Indonesia. Juni, 10(2011), 25-33.

Wahyu, D. R. (2016). Financing to Deposit Ratio (FDR) Sebagai Salah Satu Penilaian Kesehatan Bank Umum Syariah (Studi Kasus Pada Bank BJB Syariah Cabang Serang). Jurnal Ekonomi Keuangan Dan Bisnis Islam, 7(1), 19-36. 
Raharyan, et al/Jurnal Ekonomi Syariah Teori dan Terapan Vol. 6 No. 2 Februari 2019: 243-253; ANALISIS

PENGARUH CAR DAN FDR TERHADAP EQUIVALENT RATE DEPOSITO SERTA DAMPAKNYA TERHADAP TOTAL ASET PADA INDUSTRI PERBANKAN SYARIAH DI INDONESIA PERIODE JANUARI 2013 - APRIL 2018 DENGAN PATH ANALYSIS

http://www.bi.go.id/ diakses pada 18 Maret 2018

http://www.bps.go.id/ diakses pada 10 Mei 2018

http://www.ojk.go.id/ diakses pada $15 \mathrm{Mei}$ 2018

http://republika.com/ diakses 25 Juni 2018 